\title{
Giant Cell Neoplasm
}

National Cancer Institute

\section{Source}

National Cancer Institute. Giant Cell Neoplasm. NCI Thesaurus. Code C7069.

A benign, intermediate, or malignant neoplasm characterized by the presence of neoplastic giant cells. 